\title{
Molecular Fingerprints of Malignant Pleural Mesothelioma: Not Just a Matter of Genetic Alterations
}

\author{
Eugenia Lorenzini $^{1,2}$, Alessia Ciarrocchi ${ }^{1}$ (I) and Federica Torricelli ${ }^{1, *}$ \\ 1 Laboratory of Translational Research, Azienda USL_IRCCS di Reggio Emilia, 42123 Reggio Emilia, Italy; \\ eugenia.lorenzini@ausl.re.it (E.L.); alessia.ciarrocchi@ausl.re.it (A.C.) \\ 2 Department of Pharmacy and Biotechnology (FABIT), University of Bologna, 40126 Bologna, Italy \\ * Correspondence: Federica.torricelli@ausl.re.it
}

Citation: Lorenzini, E.; Ciarrocchi,

A.; Torricelli, F. Molecular

Fingerprints of Malignant Pleural

Mesothelioma: Not Just a Matter of Genetic Alterations. J. Clin. Med. 2021, 10, 2470. https://doi.org/10.3390/ jcm10112470

Academic Editors: Filippo Lococo and Emmanuel Andrès

Received: 31 March 2021

Accepted: 29 May 2021

Published: 2 June 2021

Publisher's Note: MDPI stays neutral with regard to jurisdictional claims in published maps and institutional affiliations.

Copyright: (c) 2021 by the authors. Licensee MDPI, Basel, Switzerland. This article is an open access article distributed under the terms and conditions of the Creative Commons Attribution (CC BY) license (https:// creativecommons.org/licenses/by/ $4.0 /)$.
Abstract: Malignant pleural mesothelioma (MPM) is a clinical emergency of our time. Being strongly associated with asbestos exposure, incidence of this cancer is ramping up these days in many industrialized countries and it will soon start to increase in many developing areas where the use of this silicate derivate is still largely in use. Deficiency of reliable markers for the early identification of these tumors and the limited efficacy of the currently available therapeutic options are the basis of the impressive mortality rate of MPM. These shortcomings reflect the very poor information available about the molecular basis of this disease. Results of the recently released deep profiling studies point to the epigenome as a central element in MPM development and progression. First, MPM is characterized by a low mutational burden and a highly peculiar set of mutations that hits almost exclusively epigenetic keepers or proteins controlling chromatin organization and function. Furthermore, asbestos does not seem to be associated with a distinctive mutational signature, while the precise mapping of epigenetic changes caused by this carcinogen has been defined, suggesting that alterations in epigenetic features are the driving force in the development of this disease. Last but not least, consistent evidence also indicates that, in the setting of MPM, chromatin rewiring and epigenetic alterations of cancer cells heavily condition the microenvironment, including the immune response. In this review we aim to point to the relevance of the epigenome in MPM and to highlight the dependency of this tumor on chromatin organization and function. We also intend to discuss the opportunity of targeting these mechanisms as potential therapeutic options for MPM.

Keywords: malignant pleural mesothelioma; epigenome; target therapies

\section{Introduction}

Malignant pleural mesothelioma (MPM) is a very rare but aggressive cancer arising from the mesothelial cells lining the lungs' pleura [1-5].

It is characterized by a high mortality rate and a dismal prognosis due to limited treatment options available. Over $80 \%$ of MPMs are associated with professional or environmental chronic asbestos exposure, even if difficulties in tracking this contaminant and the long latency period between the exposure and tumor development make this percentage largely underestimated. Despite asbestos restrictions, incidence and mortality rates for this cancer are expected to rise in the next decade in many industrialized countries. As well, a considerable increase of MPM cases is predicted in emerging economies, including China and India, where asbestos is still largely used [6].

Morphologically, three main MPM histotypes can be recognized, reflecting the degree of cell differentiation, that also mirror different clinical behaviors: epithelioid, sarcomatoid, and biphasic MPM [5,7], with the sarcomatoid subtype being the most aggressive and the one with the worst prognosis [8].

The molecular basis of this disease remains largely unknown, currently representing the most relevant limitation to the development of effective MPM targeting strategies [9]. 
Insights into the genetic landscape of this tumor by recent deep sequencing studies revealed a quite low mutational burden and only few pathologically important mutations. Furthermore, no specific genetic changes that can be attributed to the action of asbestos could be identified $[8,10,11]$.

Instead, increasing evidence points to the epigenome as a primary target of asbestos and as a central hub in the genesis and progression of mesothelioma. An extremely large number of loci, many of which are implicated in cell cycle regulation, have been shown to be epigenetically altered in MPM and to correlate with asbestos exposure. Logically, with an epigenome-based evolution of MPM its decades-long latency would allow ample time for cellular turnover and selection of cells with altered epigenetic programs, thus favoring survival and deregulated proliferation.

Chromatin plasticity is at the basis of many fundamental processes like transcription, chromosome condensation, and DNA Damage Repair (DDR). All these processes are busted in cancer to keep up with the massive proliferation capacity of tumor cells. Furthermore, consistent evidence has demonstrated that chromatin rewiring may heavily condition the cancer microenvironment, including immune response [11-13].

In this review we aim to point to the relevance of the epigenome in MPM and the dependency of this tumor on chromatin organization and function.

Literature from the very early days of mesothelioma research was considered and included, as well as the most recent data published at the beginning of 2021, resulting in 121 references.

\section{Asbestos-Mediated Epigenetic Changes}

The majority of MPM cases are a consequence of chronic asbestos exposure. Asbestos consists of a group of naturally occurring silicate minerals that were largely used in the sectors of industry and construction until a few decades ago [14]. Asbestos fibers are associated with the development of both malignant (lung cancers, mesothelioma) and non-malignant (asbestosis) diseases [15]. Noticeably, while asbestos is known to cause genotoxicity through DNA breaks and oxidative damage, no association between asbestos exposure and a precise and recurrent MPM mutational profile could be established, thus failing to identify an asbestos-associated mutational signature at the origin of MPM $[8,11,16]$.

By contrast, evidence indicates that asbestos is associated with epigenetic changes even if the molecular mechanisms through which this occurs are not fully understood. Inhalation of asbestos fibers results in their deposition in the lungs, causing a profound inflammatory response that involves the continuous production of free radicals, reactive oxygen (ROS) and nitrogen (RNS) species $[3,17,18]$. ROS and RNS collide with cellular components, promoting DNA mutation and triggering transformation [14,19]. Moreover, the majority of asbestos fibers contain iron. Iron ions $\left(\mathrm{Fe}^{2+}\right)$ are able to induce hemolysis, sequestering iron from hemoglobin and releasing it [14]. Free iron is the catalyst of the Fenton reaction that results in the generation of hydroxyl radicals $(\mathrm{OH})$. These radicals can oxidate DNA, proteins, and other biological molecules, damaging them [20]. In particular, $\mathrm{OH}$ can hydroxylate the $\mathrm{C} 8$ position of deoxyguanosine, forming 8-hydroxy-2'-deoxyguanosine (8-OHdG), thus generating DNA base mispairing and G-to-T transversions [21].

The inflammatory process is exacerbated by the activation of macrophages that are stimulated, among others, by the release of high-mobility group box 1 protein (HMGB1) as well as the secretion of TNF-alpha and other inflammatory cytokines in the intercellular spaces.

These pro-inflammatory molecules converge upon the activation of NF-Kb, which helps human mesenchymal-damaged cells to survive and thus promotes tumor establishment and progression [22,23].

While acute production of ROS generates largely reparable DNA mutations, exposure to chronic ROS production, like the one imposed by the asbestos fibers, produces a dangerous stressed microenvironment in which consequences are harder to overcome [24] (Figure 1). 


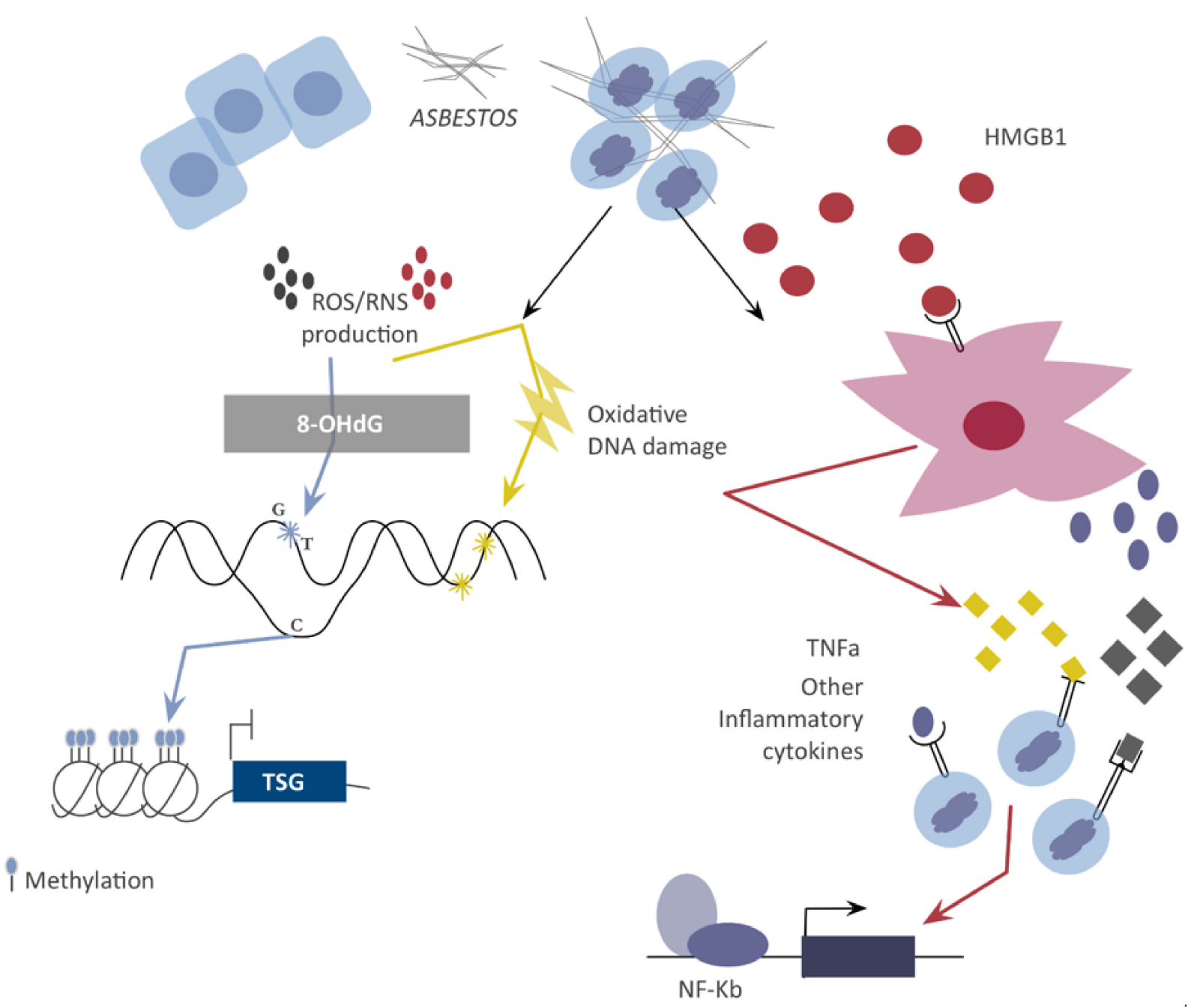

Figure 1. Inhalation of asbestos fibers causes an inflammatory response in the lungs that results in the chronic production of ROS and RNS. These reactive species collide with biological molecules, damaging them. In particular, 8-OhdG can generate DNA base mispairing, resulting in G-to-T transversions. Moreover, DNA methylation is vulnerable to asbestos fibers that, indeed, are a cause of tumor suppressor genes (TSGs), promoting hypermethylation and subsequent silencing. Additionally, mesothelial cells exposed to asbestos undergo necrosis, releasing HMGB1 into the intercellular space and thus recruiting macrophages and stimulating the chronic inflammation response. Activated macrophages release TNF-alpha and other inflammatory cytokines that result in NF-kB. Activation leads to consequent survival of HM cells with genetic damage. These two mechanisms work together to trigger tumor formation and growth. List of abbreviations: ROS-reactive oxygen species, RNS—reactive nitrogen species, TSGs—-tumor suppressor genes, HMGB1—high-mobility group box 1, TNFa-tumor necrosis factor alpha.

This chronic inflammation caused by the exposure to asbestos also impacts the overall epigenetic landscape of HM cells, in particular via the alteration of their methylation profile. Relevant evidence supports an association of asbestos and chronic inflammation with hypermethylation of crucial oncosuppressor genes [25] with an impact also on clinical outcomes of MPM patients [26]. Moreover, asbestos exposure seems to be involved in microRNA expression. Alterations in these molecules induce epigenetic changes favoring MPM development and progression (see below) [27-30].

\section{The Genomic Landscape of MPM Is Characterized by Alterations in Epigenetic Keepers}

Deep analysis of the genomic landscape of MPM showed that this tumor is characterized by a low mutational burden with a mean of $<2$ somatic non-synonymous mutations per megabase and few recurrent gene mutations [11]. Furthermore, studies have high- 
lighted that MPM is characterized by a quite peculiar set of alterations hitting in particular proteins involved in chromatin organization and epigenetic keepers.

$B A P 1$ is a deubiquitinating enzyme that binds to the breast cancer type 1 susceptibility protein (BRCA1) via the RING finger domain, and through this mechanism participates in genome stability by affecting DNA repair, cell-cycle checkpoints, heterochromatin formation, and centrosome amplification. BAP1 acts as a tumor suppressor gene and mutations disrupting its deubiquitinase activity or its nuclear localization abolish this function and drive cancer development [31]. Indeed, germline mutations in BAP1 have been shown to be associated with an increased risk of developing MPM as well as other types of cancer, primarily melanoma. Furthermore, deep mutational profiling showed that $B A P 1$ is inactivated by either copy number or point mutations in about $57 \%$ of MPM cases, representing the most frequent alteration in this type of cancer. BAP1 mutations seem to be associated to the epithelioid phenotype but not to a different prognosis [11]. Besides its function in DNA repair and genomic stability, BAP1 also affects gene expression by altering histones' post-translational modifications and chromatin accessibility. Furthermore, a direct activity of $B A P 1$ in defining stability of many transcription factors has been reported. Gene expression profiling of BAP1 wild-type (wt) tumors showed profound changes in the transcriptional program of MPM cells. One thousand three hundred twenty-four genes were found differentially expressed in BAP1 mutated tumors, including several HOXA genes as previously noted in experimental models [32]. In addition, among many TFs, YY1 had significantly reduced activity in BAP1-defective MPM cells. BAP1 is known to form a complex with YY1 and HCF1 that represses transcription of genes involved in cell proliferation [33].

NF2, TP53, LATS2, SETD2, and to a lesser extent SETDB1 are also found as frequently mutated in MPM. All five genes have high rates of nonsense, frameshift, and splice-site mutations causing their inactivation, in line with their functions as tumor suppressors. SETD2 and $F$ are both histone lysine methyltransferases. As BAP1 alters the post-translational state of histones, these proteins control chromatin functions and the dynamics of many crucial processes, including DNA repair and gene expression.

SETD2 is responsible for trimethylation of histone H3K36, which is found in gene coding regions and is associated with transcriptional elongation, peaking at the $3^{\prime}$ ends of genes [34].

SETD2-dependent H3K36 trimethylation facilitates several processes within the cell, including splicing, repression of intragenic transcripts, and chromatin accessibility. SETD2 is required in human cells for homologous recombination repair and in genome stability [35]. In fact, SETD2-deficient cancers exhibit a wide range of mutations, including insertions, deletions (indels), and chromosomal aberrations [36,37].

SET domain bifurcated histone lysine methyltransferase 1 (SETDB1) catalyzes histone 3 lysine 9 methylation, generating $\mathrm{H} 3 \mathrm{~K} 9 \mathrm{me} 2$ and $\mathrm{H} 3 \mathrm{~K} 9 \mathrm{me} 3$ histone marks. These modifications, preferentially associated to gene expression silencing, have been reported to hit on several pivotal genes involved in normal cell functions, such as TP53. Recent studies reported the overexpression of SETDB1 in most cancer types, where it promotes cell proliferation, migration, and invasion [38]. Conversely, in MPM a significant percentage of loss of function mutations were detected in SETDB1, suggesting a different, not-yet-fully elucidated role of this gene in this type of tumor [39].

The neurofibromatosis 2 (NF2) gene is inactivated in $40-50 \%$ of MPM cases [40-43]. NF2 is a tumor suppressor gene that encodes the moesin-ezrin-radixin-like (Merlin) protein that is associated with the actin cytoskeleton [42-44].

In its dephosphorylated form, Merlin accumulates in the nucleus where it inhibits the pro-oncogenic function of the E3 ubiquitin ligase CRL4 (DCAF1), thus conditioning the expression of several oncogenes [44,45]. In addition, Merlin inactivation leads to mTOR upregulation, promoting cell proliferation [46].

Moreover, Merlin loss, together with the inactivation of LATS2 in a small number of patients, is believed to contribute to tumorigenesis through inactivation of the Hippo 
pathway [47]. As with Merlin, LATS2 is also subject to point mutations and/or large deletions in about $11 \%$ of patients [48]. LATS2's loss of function mutations correlates with bad prognosis $[11,49,50]$.

Miyanaga et al. found alterations in the Hippo pathway both at the DNA and protein levels in several MPM cell lines and patients [51]. These perturbations lead to Hippo pathway inactivation with the consequent activation of the oncogene YAP1, which promotes the transcription of several cancer-promoting genes [47]. Moreover, YAP1 is often amplified in mesothelioma. YAP1 silencing by RNAi causes growth inhibition of MPM cells [51].

Bueno et al. found TP53 to be mutated in $8 \%$ of cases, a number higher than previously reported [8], but lower than in studies involving a smaller sample size [40]. However, TP53 is rarely mutated compared to other cancer types. TP53 mutations were absent from the epithelioid subtype. Moreover, patients with TP53 mutations showed lower overall survival than those with wild-type TP53, indicating the aggressiveness of TP53-mutant MPMs [8]. While all these studies provide precious details on the molecular basis of MPM, the wide genetic complexity and heterogeneity that emerge as specific features of this disease make it very difficult to translate this information in tools to improve patient management. In this regard, the use of algorithms or mathematical models integrating different types of information together with the genetic profile of the lesion will likely provide a better chance to assess the applicability of genetic analysis to resolve stratification of MPM patients.

\section{Morphological Differentiation in MPM Is a Matter of Altered Gene Expression}

In spite of extensive profiling, the most efficient MPM classification is based on morphology. According to a histological evaluation of cell differentiation, MPMs are subdivided in three main categories, epithelioid, sarcomatoid, and biphasic, the latest being a mixture of the other subtypes. Morphological grading also offers the best measure of risk stratification of these tumors, being that sarcomatoid the most aggressive and deadly form of MPM. Even if some attempts have been performed [52,53], genetic alterations seem not to account for this diversity. By contrast, hierarchical clustering on the basis of deep gene expression profiling always recapitulates these three categories, with biphasic MPM always in a wide and largely heterogeneous spectrum in between the other two histotypes. Recently, Blum and colleagues $[54,55]$ have proposed that distinct morphological phenotypes correspond to distinct transcriptomic programs, thus MPM should be considered as a molecular gradient in between the two extreme differentiation phenotypes. Coupling deep transcriptional and epigenetic profiles with a deconvolution approach, these authors proposed that each MPM is a combination of a molecular epithelioid-like and sarcomatoid-like components. Proportion of these components was a reflection of histology and was strongly correlated with prognosis. In agreement, Hmeljak and colleagues [11] using multi-omic data from the TCGA cohort, showed that classification based on RNA profiles (including both coding and non-coding RNAs) is a good surrogate for the evaluation of MPM heterogeneity and reflects, even if in a finer way, the histological classification. On the one hand, this evidence provides new information about how epigenetic rewiring contributes to intra- and intertumoral heterogeneity in MPM and how such activity conditions clinical behavior in MPM. On the other, it offers new and finer instruments for MPM risk stratification, paving the way to more precise and tailored treatment approaches.

\section{Epigenetic Events in MPM}

Epigenetic modifications significantly affect gene expression and regulation without altering the DNA sequence. Epigenetic mechanisms are involved in several cellular processes, including tumorigenesis [56]. They include DNA methylation, histone modifications and chromatin remodeling. Moreover, non-coding RNAs such as micro-RNAs (miRNAs) and long non-coding RNAs, act as epigenetic regulators. Epigenetic alterations are being extensively studied in recent years since they are emerging as potential tools for an improved diagnosis and prognosis of MPM. 


\subsection{DNA Methylation of Tumor Suppressor Genes}

DNA methylation involves the addition of a methyl group to the fifth carbon of the cytosine base, forming 5-methyl-cytosine. This reaction is catalyzed by a family of enzymes called DNA methyltransferases (DNMTs). This modification usually affects cytosines within CpG islands in promoters and other regulatory regions, causing the compaction of the chromatin structure. Promoter methylation inhibits the binding of the transcriptional machinery, resulting in gene silencing [57]. Global hypomethylation, together with the hypermethylation of many tumor suppressor genes (TSGs), is a signature of most cancer types, including MPM [58].

There are several studies reporting hypermethylation of TSG promoter in MPM as a consequence of asbestos exposure [12,26,59-64]. Christensen et al. compared the DNA methylation status of 803 cancer-associated genes in 158 mesothelioma specimens to 18 normal pleura samples [26]. They found a different methylation profile between tumor and normal tissue, and an association between higher methylation status and shorter overall survival. Moreover, they found a positive correlation between the methylation status and asbestos exposure. The genes that showed a different methylation state belonged to epigenetic regulation, cell cycle control, inflammation, and other pathways [26]. The same group also reported promoter hypermethylation, caused by asbestos exposure, in six cell cycle related genes (APC, CCND2, CDKN2A, CDKN2B, HPPBP1, and RASSF1), likely leading to an uncontrolled proliferation [12].

Goto et al. compared the methylation profiles of asbestos-associated MPM and lung adenocarcinoma samples [13], showing a common track of epigenetic modifications reaching $70 \%$ of deregulated genes. TMEM30B, KAZALD1, and MAPK13 were selectively hypermethylated in MPM and their degree of methylation affected patients' prognoses. In agreement with the negative prognostic value of DNA epigenetic modifications, hypermethylation was shown to be associated with advanced-stage and sarcomatoid phenotype [13].

Among TSGs epigenetically silenced in MPMs, many members of the secreted frizzledrelated proteins (SFRPs), known as inhibitors of the Wnt pathway, have been reported [65]. Intriguingly, methylation in the promoters of these genes could be detected in patients' plasma samples even if the small sample size investigated precluded a definitive conclusion. $[61,66]$.

ZIC1 encodes for a family of zinc finger transcription factors involved in apoptosis. It acts as a tumor suppressor by inhibiting miR-23a and miR-27a, the overexpression of which is correlated to a shorter survival of MPM patients [67].

Interestingly, a differential distribution of methylation profiles was reported between the epithelioid and sarcomatoid subtypes. While in the sarcomatoid samples methylation changes occurred in particular within CpG sites, modifications in the epithelioid subtype were more widely distributed across the genome in non-CpG sites [54].

Besides affecting gene expression, methylated $\mathrm{CpG}$ sites are also prone to deamination, leading to missense mutations in cancer-related genes, thus contributing to the overall genomic instability [68].

It has also been reported that cytokines produced in response to the inflammation caused by asbestos exposure can dysregulate expression and/or targeting of methyltransferases (DNMTs) during the progression of MPM. Indeed, McLoughlin et al. found that the three major methylases are overexpressed in most of MPM cell lines [69]. The data from TCGA show that patients with overexpressions of DNMT1, DNMT3a, and DNMT3b have a higher level of methylation and, therefore, a shorter overall survival.

\subsection{Histone Modifications and MPM}

Histone modifications also affect gene expression, being responsible for the loosening and compacting of the chromatin structure. A causative association between histone modifications and MPM has not been fully established. Still, many of the genes known to be mutated in MPM (including BAP1, SETD2, and SETDB1) control histone post-translational features by primarily affecting their ubiquitination and methylation status. Furthermore, 
scattered evidence indicates a potential link between global chromatin acetylation and this disease. A decrease of acetylation of histones $\mathrm{H} 3$ and $\mathrm{H} 4$ is a common mechanism observed in various types of cancer and has been reported also in MPM [70,71]. Histone acetylation results in chromatin relaxation with consequent gene expression activation [72] Lysine acetylation and deacetylation are catalyzed by histone acetyltransferases (HATs) and histone deacetylases (HDACs), respectively [73,74]. HDAC1 and HDAC2 are often dysregulated in many human malignancies, representing important therapeutic targets. Indeed, several HDAC inhibitors have been developed and show promising results for the treatment of many cancers, in particular hematological diseases. Sacco et al. found that $B A P 1$ modulates the expression of $H D A C 2$, and indeed $B A P 1$ loss is linked to reduced expression of $H D A C 2$, which in turn results in increased levels of $H D A C 1$. In fact, a compensatory mechanism has been reported, so when $H D A C 2$ levels are low, $H D A C 1$ amounts increase. An increased sensitivity to HDAC inhibitors was observed following $H D A C 2$ or BAP1 depletion, but not after HDAC1 loss. Therefore, even if the total HDAC activity is maintained, it is likely that each isoenzyme has specific roles, and this finding suggests that specific inhibitors for $H D A C 2$ could drive more precise targeted therapy. The study opens the door for further investigations on sensitivity to HDAC inhibitors in patients with BAP1 loss [75].

\subsection{Micro RNAs}

Non-coding RNAs are emerging as new key players in genomic function organization [76]. Micro RNAs (miRNAs) are short RNA molecules 18-25 nucleotides in length. Micro RNAs play different roles in several biological processes, both physiological and pathological. They exploit their function at a post-transcriptional level by binding to target mRNAs in a sequence-specific manner. A single miRNA can regulate several mRNAs and each mRNA can be regulated by different miRNAs. Micro RNA binding to its target mRNA results in its degradation, inhibiting its translation [77,78]. Micro RNAs are already used as diagnostic tools for several diseases, and they can be found both in tissues and in biological fluids $[79,80]$. Many studies were carried out to explore the specific miRNA expression profile of MPM. It was reported that asbestos causes overexpression of miR-374a, miR-24-1, let-7d, let-7e, miR-119b-5p, miR-331-3p, and miR-96 and downregulation of miR-939, miR-671-5p, miR-605, miR-1224-5p, and miR-202 [81,82]. Reid et al. found a downregulation of the miRNA 15/16 family in MPM tumors compared to normal mesothelial tissue. Moreover, overexpression of miR-16 inhibited proliferation of MPM cells [83]. Additionally, miR-16 acts as a tumor suppressor gene and its expression was correlated to patients' survival $[84,85]$. Downregulation of miR-16, together with downregulation of miR-15b, miR-195, and miR-200c, is associated with an increased expression of programmed death-ligand 1 (PDL1) [28].

Another tumor suppressor gene that is often downregulated in MPM patients is miR-17 [85].

Downregulation of miR-126 is associated with upregulation of VEGF, resulting in increased vascularization and enhanced metastasis. Several studies observed a downregulation of this miRNA in MPM patients' plasma [85-87], but the discrimination between MPM patients and controls was not very high.

\section{Epigenetic Features as Diagnostic and Prognostic Markers in MPM}

While the etiology of MPM is becoming clearer due to recent genomic studies, poor advances have been made in the daily management of the disease. MPM is usually diagnosed in advanced stages, when treatments and procedures are very limited and not very effective. Thus, tools that may improve diagnosis and prognosis of MPM patients are currently an urgent clinical need.

Some of the epigenetic modifications reported above can be detected in biological fluids, such as plasma, serum, urine, or cerebrospinal fluid. These molecules, reported as "circulating biomarkers", are receiving particular attention with regard to cancer diagnosis 
for their non-invasive collection method [88]. Moreover, epigenetic alterations have been often found in early-stage patients [24,69], thus representing a promising tool for an early diagnosis.

Very few studies have focused on alterations of DNA methylation in blood as circulating markers of MPM, and, in spite of the promising results, the seemingly limitless results gathered from this type of analysis are so far a major issue in the translational applicability of this information. Recently, DNA methylation status was investigated in the peripheral blood of 163 MPM patients and compared to 137 healthy controls. The analysis revealed more than 800 differentially methylated CpG sites in the MPM cohort. The three major hypomethylated $\mathrm{CpG}$ sites corresponded to FOXK1, MYB, and TAF4, while the most hypermethylated CpG sites were CXCR6/FYCO1, TAP1, MORC2, and LIME1. These differentially methylated $\mathrm{CPG}$ sites showed a diagnostic value, and the results were stable across the different MPM histotypes [89].

In a separate study, Fischer et al. used two-stage methylation-specific PCRs to study the methylation status of nine promoters in the serum DNA of 43 patients with malignant mesothelioma, showing that the combined hypermethylation of RAR $\beta, D A P K$, and RASSF1A promoters, known for their tumor-suppressor activities, was associated with shorter overall survival [90]. While promising, some considerations must be undertaken in evaluating the transferability of these applications in real life. First, circulating DNA levels are widely influenced by dimension, state, and diffusion of the tumor. Moreover, DNA methylation detected in blood only partially reflects the methylation state of the tumor component, being largely representative of the activation of immune response toward cancer cells and/or other systemic biological processes. Surely, the use of larger and homogenous patients' cohorts is needed in order to define the real potential of these applications as diagnostic or prognostic biomarkers in MPM.

Over the past decade, several studies have been conducted to explore circulating miRNAs in MPM (reviewed in $[88,91]$ ). Santarelli et al. reported a downregulation of miR-126 in serum samples of MPM patients compared to either asbestos-exposed people or unexposed healthy controls. However, the sensitivity and specificity of this marker was modest. Additionally, miR-103 was downregulated in the blood of 23 MPM patients compared either to 17 people exposed to asbestos or 25 healthy controls. The discrimination between these groups based on miR-103 expression was higher than on miR-126 expression [92].

These data were confirmed by Tomasetti et al., who, in a cohort of 45 MPM patients and 56 healthy controls, showed that miR-126-3p discriminates MPM patients with a sensitivity of $80 \%$ and a specificity of $60 \%$ [87]. Noticeably, the diagnostic performance of $\mathrm{miR}-126-3 \mathrm{p}$ seemed significantly improved when combined with the analysis of mesothelin and methylation of the thrombomodulin promoter (AUC 0.857, 95\% CI 0.767-0.927) [93].

For the first time, Cavalleri et al. explored the miRNA expression profile in extracellular vesicles, finding a differential expression between MPM patients $(n=23)$ and asbestos-exposed healthy subjects $(\mathrm{n}=19)$. They identified the combination of miR-103a-3p and miR-30e-3p as the most discriminating one, generating an AUC of 0.942 (95\% CI $0.87-1.00$ ) with a sensitivity of $95.5 \%$ and a specificity of $80 \%$ [94]. As well, Kirschner et al. showed that higher serum levels of miR-625-3p discriminate MPM patients from asbestosexposed healthy subjects with an accuracy of $79.3 \%$, sensitivity of $70 \%$, and specificity of $90 \%$ [95].

Serum analysis of miR-548a-3p and miR-20a levels in 60 MPM patients revealed overexpression of both in comparison with 20 asbestos-exposed people and 20 healthy subjects. The combination of the two miRNAs reached a sensitivity of 100\% [96]. A recent study showed that high levels of the long non-coding RNA RP1-86D1.3 and miR-2053, together with low levels of damage-regulated autophagy modulator (DRAM1) and arylsulfatase A (ARSA) mRNAs, were associated with MPM and could efficiently discriminate MPM $(n=100)$ from exposed or not healthy subjects. Moreover, the authors suggest that the upregulation of miR-2053 could also be a good prognostic marker of MPM [97]. 
Lamberti et al. compared miRNA expression in the serum of 14 MPM patients to 10 controls and observed upregulation in five miRNAs (miR-101, miR-25, miR-26b, miR-335, and miR-433) and downregulation in two miRNAs (miR-191 and miR-223). Based on these results, they proposed two miRNA signatures using different combinations of up- and downregulated miRNAs for histotype and survival predictions [98].

Considering together all these studies, the possibility of considering circulating miRNAs as potential diagnostic and/or prognostic biomarkers for MPM has been attempted for almost ten years without reaching a definitive consensus.

This is in part attributable to technical limitations like different methodologies, choice of normalization methods, and types of controls. Additionally, a major drawback of these studies is the fact that they were performed on cross-sectional cohorts and focused on patients with late-stage diseases, leaving unexplored the performance of miRNAs as early diagnostic markers.

Indeed, when tested in this context, as recently demonstrated by Weber and colleagues, who investigated miR-132-3p, miR-126-3p, and miR-103a-3p in prediagnostic plasma samples, miRNAs fail to detect cancer, showing their limitation as early detection markers for malignant mesothelioma [99].

\section{Epigenetics and Microenvironments a Dangerous Crosstalk in MPM}

Clinical management of MPM is highly challenging. Part of this challenge is due to the intimate connection of MPM cells with the surrounding microenvironment.

Several studies have highlighted the complex role that both local and systemic inflammation plays in the development and progression of many types of cancer, including MPM [100]. The activation of local immune response seems to be correlated in MPM with an aggressive disease and worse prognosis [101,102]). A very heterogenous immune infiltrate has been described in MPM with a predominant role for tumor-associated macrophages (TAM) and tumor-infiltrating CD4+ and CD8+ T lymphocytes. Different frequencies of these cells in the tumor milieu seems to hold specific prognostic value. Together with additional infiltrating stromal cells like cancer-associated fibroblasts (CAFs), these immune populations secrete pro-inflammatory signals that create a very reactive local environment. Many of these signals, including TGFb or pro-inflammatory cytokines, are known to trigger intracellular downstream signals that converge on changes in the gene expression program of cancer cells by affecting the epigenomic landscape of these cells (reviewed in [103]).

Indeed, consistent evidence demonstrates that chromatin rewiring in cancer cells is heavily conditioned by the microenvironment and, in turn, changes in the epigenome of the tumor may alter features of the neighboring cells. The immune system plays a fundamental role in this regard. We have already mentioned how the massive inflammatory state of the microenvironment promotes MPM development and progression, hitting, among others, on the epigenome of cancer cells.

Chronic inflammation of the pleura caused by asbestos exposure during MPM development triggers apoptosis or necrotic death of mesothelial cells, inducing the release of alarmins and the accumulation of nucleosides and nucleotides in the extracellular pleura space. These molecules are able to induce an immunosuppressive effect and accelerate metastasis, influencing the signaling necessary for macrophages and cytotoxic T-lymphocytes activation [104]. Sigalotti et al. [105] showed for the first time that the cancer testis antigens (CTAs), which are completely absent in healthy tissues, are highly expressed, even if with heterogeneous levels, in MPM cells. Expression of CTAs is usually linked to cancer progression and negative immunomodulation, being able to be recognized by macrophages and dendritic cells and to block their antitumor activity. CTA expression is known to be primarily regulated by epigenetic events. In particular, both DNA methylation and histone modification silence these genes under normal conditions.

At the same time, various HDAC inhibitors, such as sodium butyrate, SAHA, and valproic acid, have been demonstrated to have important anti-inflammatory properties, affecting the expression of pro-inflammatory cytokines and promoting the differentiation 
of naïve CD4+ T lymphocytes into regulatory $\mathrm{T}$ cells (Tregs) with increased immunosuppressive activity [104].

\section{Targeting Epigenome: New Strategies for Potential Therapies}

MPM is usually diagnosed in advanced stages when surgical treatments are often limited. Surgery, chemotherapy, and radiotherapy have so far been the only therapeutic options. Recently, the open-label phase III CheckMate 743 clinical trials showed that administration of ipilimumab plus nivolumab results in a significant improvement of patients' survival (median OS 18.1) as compared to standard chemotherapy, thus providing the basis for the introduction of immunotherapy as an additional therapeutic option for MPM patients [106]. In spite of this, these strategies often reach only modest therapeutic effects, leaving MPM patients with poor life expectancy [107], suggesting the urgent need for new treatment approaches for this tumor. In parallel, the development of MPM-oriented target therapies has been so far limited by both lack of activating driver mutations and the limited knowledge about the molecular basis of this tumor. The collective amount of evidence pointing to epigenetic alterations as important determinants in MPM development and prognosis lays instead the groundwork for numerous preclinical and clinical studies using epigenetic drugs to target MPM (Table 1).

Indeed, inactivation of tumor suppressor genes, driven by promoter hypermethylation [58] and chromatin hypoacetylation [70], is a distinctive feature of MPM, paving the way for the use of DNMT inhibitors (DNMTis) and HDAC inhibitors (HDACis) in several preclinical studies alone or in combination with traditional chemotherapy.

In 2009, in vitro studies showed that the use of the HDACi valproic acid coupled with cisplatin and pemetrexed in MPM cell lines was effective in inducing caspase-dependent apoptosis, and the same treatment performed in mouse xenograft models showed complete suppression of MPM growth [108,109]. Successively, a phase II study tested a combination of valproic acid with doxorubicine in second-line therapy of MPM patients, observing a partial response in 6/45 patients with a good performance status [110].

In line with these data, Hurwitz et al. demonstrated the overexpression of FLICEinhibitory protein (FLIP) and procaspase 8 in MPM patients and the efficacy of the HDACi SAHA (vorinostat) in inducing FLIP downregulation and Caspase 8 activation with a consequent apoptotic response in MPM cells [111]. Moreover, a combination of vorinostat with cisplatin in MPM cell lines resulted in higher induction of apoptosis when compared with either agent alone [111]. However, in 2015 a phase III randomized, placebo-controlled trial comparing vorinostat versus a placebo in second- and third-line therapy of MPM patients observed no significant improvement in overall survival [112].

The lack of effect of this single drug in MPM cannot be considered totally unexpected and was suggested in several preclinical studies regarding its combination with DNA demethylating agents.

It was demonstrated that the 5-aza-2' deoxycytidine (decitabine), a DNA methyltransferase inhibitor, is able to increase the expression of genes involved in DDR and cell cycle regulation, inducing a growth arrest of MPM cells typical to senescence [113].

Additionally, decitabine alone or in combination with two different HDACis (valproic acid and SAHA) was used to treat MPM cells. Results showed a synergic effect between these two distinct classes of drugs in inducing tumor-associated antigen expression and consequent activation of cytotoxic T cell response. Moreover, the sequential treatment of murine models of mesothelioma with decitabine and valproic acid was demonstrated to significantly reduce tumor progression [114]. The same researchers, in a subsequent paper, obtained similar results testing new more potent and convenient HDACis in combination with decitabine. Besides confirming the cytotoxicity of these drugs, these authors also supported the rational for the combination of epigenetic drugs with an anti-PD-L1 targeting strategy [115] and further highlighted the tight connection existing between epigenetic re-wiring and the cancer microenvironment. 
Since the discovery of the role of super-ENHs and of the importance of BRD4 and BET proteins in their activation [116], BET-targeting agents (BETis) were regarded as promising drugs in cancer. In 2018, Riganti et al. [117] tested the efficacy of BETis in MPM cells, demonstrating the capability of these drugs to induce an immunogenic response against MPM cells and showing that JQ1 treatment restrains tumor growth in immunocompetent MPM mouse models. Being better tolerated than methyltransferase inhibitors and HDACis [118], these drugs may become a more effective way to target alone or in combination the epigenome of MPM.

In spite of promising preclinical data and a solid rationale, clinical trials testing epigenetic drugs' efficacy in MPM are rare, likely due to the high toxicity of these compounds and their short half-life and poor body distribution that limited their use in patients with solid tumors [69].

Still, the mechanicistic synergy that these drugs have with other anticancer drugs suggests that the accurate design of combinatory trials for converging on specific biological processes would be a potential strategy for the employment of these drugs in the management of many solid cancers that, like MPM, have very few targeted therapies available $[119,120]$. In this regard, the recent indication of immune therapy efficacy in treating MPM opens a new and still partially explored route. Indeed, all classes of epigenetic drugs have been shown to modulate immune response acting either on immune cells infiltrating the tumors or in modulating the crosstalk between cancer and immune cells via the modulation of specific mediators. Several ongoing trials are testing combinations of HDACis or BETis with immunotherapic agents in several settings and providing encouraging preliminary evidence [121].

Table 1. Epigenetic drugs tested in clinical and preclinical trials for MPM treatment.

\begin{tabular}{|c|c|c|c|c|}
\hline Drug & $\begin{array}{l}\text { In Combination } \\
\text { With }\end{array}$ & Effect & Trial & Reference \\
\hline $\begin{array}{l}\text { Valproic acid } \\
\text { (HDACi) }\end{array}$ & $\begin{array}{l}\text { Cisplatin and } \\
\text { pemetrexed }\end{array}$ & $\begin{array}{c}\text { Increased apoptosis of MPM cells; } \\
\text { suppression of MPM growth in } \\
\text { mouse } \\
\text { xenograft models }\end{array}$ & Preclinical & $\begin{array}{l}\text { Vandermeers, F. } \\
\text { et al., } 2009 \text { [108] }\end{array}$ \\
\hline $\begin{array}{l}\text { Valproic acid } \\
\text { (HDACi) }\end{array}$ & Doxorubicin & $\begin{array}{l}\text { Partial response in } 6 \text { of } 45 \\
\text { second-line MPM patients }\end{array}$ & $\begin{array}{c}\text { Phase II } \\
\text { clinical trial }\end{array}$ & $\begin{array}{l}\text { Scherpereel, A. } \\
\text { et al., } 2011 \text { [110] }\end{array}$ \\
\hline $\begin{array}{c}\text { SAHA } \\
\text { (HDACi) }\end{array}$ & - & Caspase 8 induced apoptosis & \multirow{2}{*}{ Preclinical } & \multirow{2}{*}{$\begin{array}{l}\text { Hurwitz, J.L } \\
\text { et al., } 2012 \text { [111] }\end{array}$} \\
\hline $\begin{array}{l}\text { SAHA } \\
\text { (HDACi) }\end{array}$ & Cisplatin & $\begin{array}{l}\text { Increased apoptosis compared to } \\
\text { the single drugs }\end{array}$ & & \\
\hline $\begin{array}{l}\text { SAHA } \\
\text { (HDACi) }\end{array}$ & - & $\begin{array}{c}\text { No increase in } \\
\text { patients' OS compared to placebo }\end{array}$ & $\begin{array}{l}\text { Phase III } \\
\text { clinical trial }\end{array}$ & $\begin{array}{l}\text { Krug, L.M. } \\
\text { et al., } 2015 \text { [112] }\end{array}$ \\
\hline $\begin{array}{l}\text { Decitabine } \\
\text { (DNMTi) }\end{array}$ & - & $\begin{array}{l}\text { Induction of genes } \\
\text { involved in DDR and cell cycle } \\
\text { regulation, causing premature } \\
\text { senescence induction }\end{array}$ & Preclinical & $\begin{array}{l}\text { Amatori, S } \\
\text { et al., } 2011 \text { [113] }\end{array}$ \\
\hline $\begin{array}{l}\text { Decitabine } \\
\text { (DNMTi) }\end{array}$ & $\begin{array}{l}\text { Valproic acid/ } \\
\text { SAHA }\end{array}$ & $\begin{array}{l}\text { Induction of tumor-associated } \\
\text { antigens and activation of } \\
\text { cytotoxic T cell response; } \\
\text { reduction of tumor progression in } \\
\text { mice }\end{array}$ & Preclinical & $\begin{array}{l}\text { Leclercq, S. } \\
\text { et al., } 2011 \text { [114] }\end{array}$ \\
\hline $\begin{array}{l}\text { Decitabine } \\
\text { (DNMTi) }\end{array}$ & $\begin{array}{l}\text { Newly } \\
\text { synthetized } \\
\text { HDACi }\end{array}$ & $\begin{array}{l}\text { Increase in PD-L1 } \\
\text { expression }\end{array}$ & Preclinical & $\begin{array}{l}\text { Bensaid, D. } \\
\text { et al., } 2018 \text { [115] }\end{array}$ \\
\hline JQ1 (BETi) & - & $\begin{array}{l}\text { Induction of immunogenic } \\
\text { response; } \\
\text { inhibition of tumor growth in } \\
\text { immunocompetent mice }\end{array}$ & Preclinical & $\begin{array}{l}\text { Riganti C. et al., } \\
2018 \text { [117] }\end{array}$ \\
\hline
\end{tabular}




\section{Conclusions}

MPM is still one of the most aggressive and deadly forms of cancer. Its silent evolution, the generally old age of the patients, and the lack of effective therapeutic strategies make MPM clinically hard to manage and leaves MPM patients with a very poor prognosis. Away from being an "old fashioned" disease, MPM patients require the elaboration of new strategies to improve both life expectancy and quality of life. The epigenome is the control center of gene expression. Working as a rheostat, the epigenome modulates the expression of crucial genes, thus facilitating the acquisition of essential features for cancer survival. This seems to be extremely important in MPM, which is recognized as a "loss of function" type of cancer characterized by alterations leading to inactivation of onco-suppressive genes. Epigenetic modifications increasing the structural complexity of specific loci are used to turn off the expression of such genes driving MPM progression. Additionally, epigenetic alterations in MPM may affect the way cancer cells are recognized by the immune system, leading to immune evasion and resistance to immune checkpoint inhibitors. While single-agent epigenetic drugs have shown poor applicability in treating solid cancers, used in combination with chemotherapy or other genome targeting drugs, they may represent a new therapeutic perspective regarding this tumor. Furthermore, looking at the dark side of the genome, including the exploration of non-coding RNAs, may help to shed light onto the molecular basis of this cancer, providing answers that so far are still missing.

Funding: A.C. was funded by the Italian Ministry of Health through Bando per la Valorizzazione della Ricerca in ambito Oncologico 2020-Fondi 5 per Mille. FT is founded by the Italian Ministry of Health through Fondi 5 per Mille 2017.

Institutional Review Board Statement: Not applicable.

Informed Consent Statement: Not applicable.

Conflicts of Interest: The authors declare no conflict of interest.

\section{References}

1. Robinson, B.M. Malignant pleural mesothelioma: An epidemiological perspective. Ann. Cardiothorac. Surg. 2012, 1, 491-496. [CrossRef]

2. McDonald, J.C.; McDonald, A.D. The epidemiology of mesothelioma in historical context. Eur. Respir. J. 1996, 9, 1932-1942. [CrossRef]

3. Carbone, M.; Ly, B.H.; Dodson, R.F.; Pagano, I.; Morris, P.T.; Dogan, U.A.; Gazdar, A.F.; Pass, H.I.; Yang, H. Malignant mesothelioma: Facts, myths, and hypotheses. J. Cell. Physiol. 2012, 227, 44-58. [CrossRef] [PubMed]

4. Husain, A.N.; Colby, T.; Ordonez, N.; Krausz, T.; Attanoos, R.; Beasley, M.B.; Borczuk, A.C.; Butnor, K.; Cagle, P.T.; Chirieac, L.R.; et al. Guidelines for pathologic diagnosis of malignant mesothelioma: 2012 update of the consensus statement from the International Mesothelioma Interest Group. Arch. Pathol. Lab. Med. 2013, 137, 647-667. [CrossRef] [PubMed]

5. Galateau-Salle, F.; Churg, A.; Roggli, V.; Travis, W.D. The 2015 World Health Organization Classification of Tumors of the Pleura: Advances since the 2004 Classification. J. Thorac. Oncol. 2016, 11, 142-154. [CrossRef]

6. Burki, T. Health experts concerned over India's asbestos industry. Lancet 2010, 375, 626-627. [CrossRef]

7. Galateau-Sallé, F. (Ed.) Pathology of Malignant Mesothelioma; Springer: London, UK, 2006.

8. Bueno, R.; Stawiski, E.W.; Goldstein, L.D.; Durinck, S.; De Rienzo, A.; Modrusan, Z.; Gnad, F.; Nguyen, T.T.; Jaiswal, B.S.; Chirieac, L.R.; et al. Comprehensive genomic analysis of malignant pleural mesothelioma identifies recurrent mutations, gene fusions and splicing alterations. Nat. Genet. 2016, 48, 407-416. [CrossRef] [PubMed]

9. Yap, T.A.; Aerts, J.G.; Popat, S.; Fennell, D.A. Novel insights into mesothelioma biology and implications for therapy. Nat. Rev. Cancer 2017, 17, 475-488. [CrossRef]

10. Hylebos, M.; Van Camp, G.; van Meerbeeck, J.P.; de Beeck, K.O. The Genetic Landscape of Malignant Pleural Mesothelioma: Results from Massively Parallel Sequencing. J. Thorac. Oncol. 2016, 11, 1615-1626. [CrossRef]

11. Hmeljak, J.; Sanchez-Vega, F.; Hoadley, K.A.; Shih, J.; Stewart, C.; Heiman, D.; Tarpey, P.; Danilova, L.; Drill, E.; Gibb, E.A.; et al. Integrative Molecular Characterization of Malignant Pleural Mesothelioma. Cancer Discov. 2018, 8, 1548-1565. [CrossRef] [PubMed]

12. Christensen, B.C.; Godleski, J.J.; Marsit, C.J.; Houseman, E.A.; Lopez-Fagundo, C.Y.; Longacker, J.L.; Bueno, R.; Sugarbaker, D.J.; Nelson, H.H.; Kelsey, K.T. Asbestos exposure predicts cell cycle control gene promoter methylation in pleural mesothelioma. Carcinogenesis 2008, 29, 1555-1559. [CrossRef] [PubMed] 
13. Goto, Y.; Shinjo, K.; Kondo, Y.; Shen, L.; Toyota, M.; Suzuki, H.; Gao, W.; An, B.; Fujii, M.; Murakami, H.; et al. Epigenetic profiles distinguish malignant pleural mesothelioma from lung adenocarcinoma. Cancer Res. 2009, 69, 9073-9082. [CrossRef]

14. Chew, S.H.; Toyokuni, S. Malignant mesothelioma as an oxidative stress-induced cancer: An update. Free Radic. Biol. Med. 2015, 86, 166-178. [CrossRef]

15. Shukla, A.; Gulumian, M.; Hei, T.K.; Kamp, D.; Rahman, Q.; Mossman, B.T. Multiple roles of oxidants in the pathogenesis of asbestos-induced diseases. Free Radic. Biol. Med. 2003, 34, 1117-1129. [CrossRef]

16. Casalone, E.; Allione, A.; Viberti, C.; Pardini, B.; Guarrera, S.; Betti, M.; Dianzani, I.; Aldieri, E.; Matullo, G. DNA methylation profiling of asbestos-treated MeT5A cell line reveals novel pathways implicated in asbestos response. Arch. Toxicol. 2018, 92, 1785-1795. [CrossRef] [PubMed]

17. Choe, N.; Tanaka, S.; Xia, W.; Hemenway, D.R.; Roggli, V.L.; Kagan, E. Pleural macrophage recruitment and activation in asbestos-induced pleural injury. Environ. Heal. Perspect. 1997, 105, 1257-1260. [CrossRef]

18. Chao, C.C.; Park, S.H.; Aust, A.E. Participation of nitric oxide and iron in the oxidation of DNA in asbestos-treated human lung epithelial cells. Arch. Biochem. Biophys. 1996, 326, 152-157. [CrossRef] [PubMed]

19. Robledo, R.; Mossman, B. Cellular and molecular mechanisms of asbestos-induced fibrosis. J. Cell. Physiol. 1999, 180, 158-166. [CrossRef]

20. Kamp, D.W.; Weitzman, S.A. The molecular basis of asbestos induced lung injury. Thorax 1999, 54, 638-652. [CrossRef] [PubMed]

21. Cheng, K.C.; Cahill, D.S.; Kasai, H.; Nishimura, S.; Loeb, L.A. 8-Hydroxyguanine, an abundant form of oxidative DNA damage, causes G-T and A-C substitutions. J. Biol. Chem. 1992, 267, 166-172. [CrossRef]

22. Yang, H.; Rivera, Z.; Jube, S.; Nasu, M.; Bertino, P.; Goparaju, C.; Franzoso, G.; Lotze, M.T.; Krausz, T.; Pass, H.I.; et al. Programmed necrosis induced by asbestos in human mesothelial cells causes high-mobility group box 1 protein release and resultant inflammation. Proc. Natl. Acad. Sci. USA 2010, 107, 12611-12616. [CrossRef]

23. Yang, H.; Bocchetta, M.; Kroczynska, B.; Elmishad, A.G.; Chen, Y.; Liu, Z.; Bubici, C.; Mossman, B.T.; Pass, H.I.; Testa, J.R.; et al. TNF-alpha inhibits asbestos-induced cytotoxicity via a NF-kappaB-dependent pathway, a possible mechanism for asbestosinduced oncogenesis. Proc. Natl. Acad. Sci. USA 2006, 103, 10397-10402. [CrossRef]

24. Sage, A.P.; Martinez, V.D.; Minatel, B.C.; Pewarchuk, M.E.; Marshall, E.A.; MacAulay, G.M.; Hubaux, R.; Pearson, D.D.; Goodarzi, A.A.; Dellaire, G.; et al. Genomics and Epigenetics of Malignant Mesothelioma. High Throughput 2018, 7, 20. [CrossRef] [PubMed]

25. Shames, D.S.; Minna, J.D.; Gazdar, A.F. DNA methylation in health, disease, and cancer. Curr. Mol. Med. 2007, 7, 85-102. [CrossRef]

26. Christensen, B.C.; Houseman, E.A.; Godleski, J.J.; Marsit, C.J.; Longacker, J.L.; Roelofs, C.R.; Karagas, M.R.; Wrensch, M.R.; Yeh, R.F.; Nelson, H.H.; et al. Epigenetic profiles distinguish pleural mesothelioma from normal pleura and predict lung asbestos burden and clinical outcome. Cancer Res. 2009, 69, 227-234. [CrossRef]

27. Kirschner, M.B.; Cheng, Y.Y.; Armstrong, N.J.; Lin, R.C.; Kao, S.C.; Linton, A.; Klebe, S.; McCaughan, B.C.; van Zandwijk, N.; Reid, G. MiR-score: A novel 6-microRNA signature that predicts survival outcomes in patients with malignant pleural mesothelioma. Mol. Oncol. 2015, 9, 715-726. [CrossRef] [PubMed]

28. Kao, S.C.; Cheng, Y.Y.; Williams, M.; Kirschner, M.B.; Madore, J.; Lum, T.; Sarun, K.H.; Linton, A.; McCaughan, B.; Klebe, S.; et al. Tumor Suppressor microRNAs Contribute to the Regulation of PD-L1 Expression in Malignant Pleural Mesothelioma. J. Thorac. Oncol. 2017, 12, 1421-1433. [CrossRef]

29. Johnson, T.G.; Schelch, K.; Cheng, Y.Y.; Williams, M.; Sarun, K.H.; Kirschner, M.B.; Kao, S.; Linton, A.; Klebe, S.; McCaughan, B.C.; et al. Dysregulated Expression of the MicroRNA miR-137 and Its Target YBX1 Contribute to the Invasive Characteristics of Malignant Pleural Mesothelioma. J. Thorac. Oncol. 2018, 13, 258-272. [CrossRef] [PubMed]

30. Nymark, P.; Guled, M.; Borze, I.; Faisal, A.; Lahti, L.; Salmenkivi, K.; Kettunen, E.; Anttila, S.; Knuutila, S. Integrative analysis of microRNA, mRNA and aCGH data reveals asbestos- and histology-related changes in lung cancer. Genes Chromosom. Cancer 2011, 50, 585-597. [CrossRef]

31. Ventii, K.H.; Devi, N.S.; Friedrich, K.L.; Chernova, T.A.; Tighiouart, M.; Van Meir, E.G.; Wilkinson, K.D. BRCA1-associated protein-1 is a tumor suppressor that requires deubiquitinating activity and nuclear localization. Cancer Res. 2008, 68, 6953-6962. [CrossRef] [PubMed]

32. LaFave, L.M.; Beguelin, W.; Koche, R.; Teater, M.; Spitzer, B.; Chramiec, A.; Papalexi, E.; Keller, M.D.; Hricik, T.; Konstantinoff, K.; et al. Loss of BAP1 function leads to EZH2-dependent transformation. Nat. Med. 2015, 21, 1344-1349. [CrossRef]

33. Yu, H.; Mashtalir, N.; Daou, S.; Hammond-Martel, I.; Ross, J.; Sui, G.; Hart, G.W.; Rauscher, F.J., 3rd; Drobetsky, E.; Milot, E.; et al. The ubiquitin carboxyl hydrolase BAP1 forms a ternary complex with YY1 and HCF-1 and is a critical regulator of gene expression. Mol. Cell. Biol. 2010, 30, 5071-5085. [CrossRef]

34. Edmunds, J.W.; Mahadevan, L.C.; Clayton, A.L. Dynamic histone H3 methylation during gene induction: HYPB/Setd2 mediates all H3K36 trimethylation. EMBO J. 2008, 27, 406-420. [CrossRef]

35. Pfister, S.X.; Ahrabi, S.; Zalmas, L.P.; Sarkar, S.; Aymard, F.; Bachrati, C.Z.; Helleday, T.; Legube, G.; La Thangue, N.B.; Porter, A.C.; et al. SETD2-dependent histone H3K36 trimethylation is required for homologous recombination repair and genome stability. Cell Rep. 2014, 7, 2006-2018. [CrossRef] [PubMed]

36. Sato, Y.; Yoshizato, T.; Shiraishi, Y.; Maekawa, S.; Okuno, Y.; Kamura, T.; Shimamura, T.; Sato-Otsubo, A.; Nagae, G.; Suzuki, H.; et al. Integrated molecular analysis of clear-cell renal cell carcinoma. Nat. Genet. 2013, 45, 860-867. [CrossRef] [PubMed] 
37. Zhu, X.; He, F.; Zeng, H.; Ling, S.; Chen, A.; Wang, Y.; Yan, X.; Wei, W.; Pang, Y.; Cheng, H.; et al. Identification of functional cooperative mutations of SETD2 in human acute leukemia. Nat. Genet. 2014, 46, 287-293. [CrossRef] [PubMed]

38. Strepkos, D.; Markouli, M.; Klonou, A.; Papavassiliou, A.G.; Piperi, C. Histone Methyltransferase SETDB1: A Common Denominator of Tumorigenesis with Therapeutic Potential. Cancer Res. 2021, 81, 525-534. [CrossRef] [PubMed]

39. Kang, H.C.; Kim, H.K.; Lee, S.; Mendez, P.; Kim, J.W.; Woodard, G.; Yoon, J.H.; Jen, K.Y.; Fang, L.T.; Jones, K.; et al. Whole exome and targeted deep sequencing identify genome-wide allelic loss and frequent SETDB1 mutations in malignant pleural mesotheliomas. Oncotarget 2016, 7, 8321-8331. [CrossRef] [PubMed]

40. Guo, G.; Chmielecki, J.; Goparaju, C.; Heguy, A.; Dolgalev, I.; Carbone, M.; Seepo, S.; Meyerson, M.; Pass, H.I. Whole-exome sequencing reveals frequent genetic alterations in BAP1, NF2, CDKN2A, and CUL1 in malignant pleural mesothelioma. Cancer Res. 2015, 75, 264-269. [CrossRef]

41. Thurneysen, C.; Opitz, I.; Kurtz, S.; Weder, W.; Stahel, R.A.; Felley-Bosco, E. Functional inactivation of NF2/merlin in human mesothelioma. Lung Cancer 2009, 64, 140-147. [CrossRef]

42. Bianchi, A.B.; Mitsunaga, S.I.; Cheng, J.Q.; Klein, W.M.; Jhanwar, S.C.; Seizinger, B.; Kley, N.; Klein-Szanto, A.J.; Testa, J.R. High frequency of inactivating mutations in the neurofibromatosis type 2 gene (NF2) in primary malignant mesotheliomas. Proc. Natl. Acad. Sci. USA 1995, 92, 10854-10858. [CrossRef]

43. Sekido, Y.; Pass, H.I.; Bader, S.; Mew, D.J.; Christman, M.F.; Gazdar, A.F.; Minna, J.D. Neurofibromatosis type 2 (NF2) gene is somatically mutated in mesothelioma but not in lung cancer. Cancer Res. 1995, 55, 1227-1231.

44. Ladanyi, M.; Zauderer, M.G.; Krug, L.M.; Ito, T.; McMillan, R.; Bott, M.; Giancotti, F. New strategies in pleural mesothelioma: BAP1 and NF2 as novel targets for therapeutic development and risk assessment. Clin. Cancer Res. 2012, 18, 4485-4490. [CrossRef] [PubMed]

45. Li, W.; You, L.; Cooper, J.; Schiavon, G.; Pepe-Caprio, A.; Zhou, L.; Ishii, R.; Giovannini, M.; Hanemann, C.O.; Long, S.B.; et al. Merlin/NF2 suppresses tumorigenesis by inhibiting the E3 ubiquitin ligase CRL4(DCAF1) in the nucleus. Cell 2010, 140, 477-490. [CrossRef] [PubMed]

46. Lopez-Lago, M.A.; Okada, T.; Murillo, M.M.; Socci, N.; Giancotti, F.G. Loss of the tumor suppressor gene NF2, encoding merlin, constitutively activates integrin-dependent mTORC1 signaling. Mol. Cell. Biol. 2009, 29, 4235-4249. [CrossRef]

47. Sekido, Y. Inactivation of Merlin in malignant mesothelioma cells and the Hippo signaling cascade dysregulation. Pathol. Int. 2011, 61, 331-344. [CrossRef]

48. Tranchant, R.; Quetel, L.; Tallet, A.; Meiller, C.; Renier, A.; de Koning, L.; de Reynies, A.; Le Pimpec-Barthes, F.; Zucman-Rossi, J.; Jaurand, M.C.; et al. Co-occurring Mutations of Tumor Suppressor Genes, LATS2 and NF2, in Malignant Pleural Mesothelioma. Clin. Cancer Res. 2017, 23, 3191-3202. [CrossRef]

49. Murakami, H.; Mizuno, T.; Taniguchi, T.; Fujii, M.; Ishiguro, F.; Fukui, T.; Akatsuka, S.; Horio, Y.; Hida, T.; Kondo, Y.; et al. LATS2 is a tumor suppressor gene of malignant mesothelioma. Cancer Res. 2011, 71, 873-883. [CrossRef]

50. Sekido, Y. Targeting the Hippo Pathway Is a New Potential Therapeutic Modality for Malignant Mesothelioma. Cancers 2018, 10, 90. [CrossRef] [PubMed]

51. Miyanaga, A.; Masuda, M.; Tsuta, K.; Kawasaki, K.; Nakamura, Y.; Sakuma, T.; Asamura, H.; Gemma, A.; Yamada, T. Hippo pathway gene mutations in malignant mesothelioma: Revealed by RNA and targeted exon sequencing. J. Thorac. Oncol. 2015, 10, 844-851. [CrossRef]

52. Torricelli, F.; Lococo, F.; Di Stefano, T.S.; Lorenzini, E.; Piana, S.; Valli, R.; Rena, O.; Veronesi, G.; Bille, A.; Ciarrocchi, A. Deep Sequencing Analysis Identified a Specific Subset of Mutations Distinctive of Biphasic Malignant Pleural Mesothelioma. Cancers 2020, 12, 2454. [CrossRef] [PubMed]

53. Torricelli, F.; Saxena, A.; Nuamah, R.; Neat, M.; Harling, L.; Ng, W.; Spicer, J.; Ciarrocchi, A.; Bille, A. Genomic analysis in shortand long-term patients with malignant pleura mesothelioma treated with palliative chemotherapy. Eur. J. Cancer 2020, 132, 104-111. [CrossRef] [PubMed]

54. Blum, Y.; Meiller, C.; Quetel, L.; Elarouci, N.; Ayadi, M.; Tashtanbaeva, D.; Armenoult, L.; Montagne, F.; Tranchant, R.; Renier, A.; et al. Dissecting heterogeneity in malignant pleural mesothelioma through histo-molecular gradients for clinical applications. Nat. Commun. 2019, 10, 1333. [CrossRef]

55. Blum, Y.; Jaurand, M.C.; De Reynies, A.; Jean, D. Unraveling the cellular heterogeneity of malignant pleural mesothelioma through a deconvolution approach. Mol. Cell. Oncol. 2019, 6, 1610322. [CrossRef] [PubMed]

56. Jones, P.A.; Baylin, S.B. The fundamental role of epigenetic events in cancer. Nat. Rev. Genet. 2002, 3, 415-428. [CrossRef] [PubMed]

57. Orphanides, G.; Reinberg, D. A unified theory of gene expression. Cell 2002, 108, 439-451. [CrossRef]

58. Zhang, X.; Tang, N.; Rishi, A.K.; Pass, H.I.; Wali, A. Methylation profile landscape in mesothelioma: Possible implications in early detection, disease progression, and therapeutic options. Methods Mol. Biol. 2015, 1238, 235-247. [CrossRef] [PubMed]

59. Christensen, B.C.; Houseman, E.A.; Poage, G.M.; Godleski, J.J.; Bueno, R.; Sugarbaker, D.J.; Wiencke, J.K.; Nelson, H.H.; Marsit, C.J.; Kelsey, K.T. Integrated profiling reveals a global correlation between epigenetic and genetic alterations in mesothelioma. Cancer Res. 2010, 70, 5686-5694. [CrossRef] [PubMed]

60. He, B.; Lee, A.Y.; Dadfarmay, S.; You, L.; Xu, Z.; Reguart, N.; Mazieres, J.; Mikami, I.; McCormick, F.; Jablons, D.M. Secreted frizzled-related protein 4 is silenced by hypermethylation and induces apoptosis in beta-catenin-deficient human mesothelioma cells. Cancer Res. 2005, 65, 743-748. 
61. Lee, A.Y.; He, B.; You, L.; Dadfarmay, S.; Xu, Z.; Mazieres, J.; Mikami, I.; McCormick, F.; Jablons, D.M. Expression of the secreted frizzled-related protein gene family is downregulated in human mesothelioma. Oncogene 2004, 23, 6672-6676. [CrossRef]

62. Wong, L.; Zhou, J.; Anderson, D.; Kratzke, R.A. Inactivation of p16INK4a expression in malignant mesothelioma by methylation. Lung Cancer 2002, 38, 131-136. [CrossRef]

63. Hirao, T.; Bueno, R.; Chen, C.J.; Gordon, G.J.; Heilig, E.; Kelsey, K.T. Alterations of the p16(INK4) locus in human malignant mesothelial tumors. Carcinogenesis 2002, 23, 1127-1130. [CrossRef]

64. Tsou, J.A.; Galler, J.S.; Wali, A.; Ye, W.; Siegmund, K.D.; Groshen, S.; Laird, P.W.; Turla, S.; Koss, M.N.; Pass, H.I.; et al. DNA methylation profile of 28 potential marker loci in malignant mesothelioma. Lung Cancer 2007, 58, 220-230. [CrossRef] [PubMed]

65. Shi, Y.; He, B.; You, L.; Jablons, D.M. Roles of secreted frizzled-related proteins in cancer. Acta Pharmacol. Sin. 2007, 28, 1499-1504. [CrossRef]

66. Cheng, Y.Y.; Mok, E.; Tan, S.; Leygo, C.; McLaughlin, C.; George, A.M.; Reid, G. SFRP Tumour Suppressor Genes Are Potential Plasma-Based Epigenetic Biomarkers for Malignant Pleural Mesothelioma. Dis. Markers 2017, 2017, 2536187. [CrossRef]

67. Cheng, Y.Y.; Kirschner, M.B.; Cheng, N.C.; Gattani, S.; Klebe, S.; Edelman, J.J.; Vallely, M.P.; McCaughan, B.C.; Jin, H.C.; van Zandwijk, N.; et al. ZIC1 is silenced and has tumor suppressor function in malignant pleural mesothelioma. J. Thorac. Oncol. 2013, 8, 1317-1328. [CrossRef]

68. Greenblatt, M.S.; Bennett, W.P.; Hollstein, M.; Harris, C.C. Mutations in the p53 tumor suppressor gene: Clues to cancer etiology and molecular pathogenesis. Cancer Res. 1994, 54, 4855-4878. [PubMed]

69. McLoughlin, K.C.; Kaufman, A.S.; Schrump, D.S. Targeting the epigenome in malignant pleural mesothelioma. Transl. Lung Cancer Res. 2017, 6, 350-365. [CrossRef] [PubMed]

70. Fraga, M.F.; Ballestar, E.; Villar-Garea, A.; Boix-Chornet, M.; Espada, J.; Schotta, G.; Bonaldi, T.; Haydon, C.; Ropero, S.; Petrie, K.; et al. Loss of acetylation at Lys16 and trimethylation at Lys20 of histone H4 is a common hallmark of human cancer. Nat. Genet. 2005, 37, 391-400. [CrossRef] [PubMed]

71. Chi, P.; Allis, C.D.; Wang, G.G. Covalent histone modifications-miswritten, misinterpreted and mis-erased in human cancers. Nat. Rev. Cancer 2010, 10, 457-469. [CrossRef] [PubMed]

72. Grunstein, M. Histone acetylation in chromatin structure and transcription. Nature 1997, 389, 349-352. [CrossRef]

73. Di Martile, M.; Del Bufalo, D.; Trisciuoglio, D. The multifaceted role of lysine acetylation in cancer: Prognostic biomarker and therapeutic target. Oncotarget 2016, 7, 55789-55810. [CrossRef] [PubMed]

74. Eckschlager, T.; Plch, J.; Stiborova, M.; Hrabeta, J. Histone Deacetylase Inhibitors as Anticancer Drugs. Int. J. Mol. Sci. 2017, 18, 1414. [CrossRef]

75. Sacco, J.J.; Kenyani, J.; Butt, Z.; Carter, R.; Chew, H.Y.; Cheeseman, L.P.; Darling, S.; Denny, M.; Urbe, S.; Clague, M.J.; et al. Loss of the deubiquitylase BAP1 alters class I histone deacetylase expression and sensitivity of mesothelioma cells to HDAC inhibitors. Oncotarget 2015, 6, 13757-13771. [CrossRef] [PubMed]

76. Rossi, T.; Pistoni, M.; Sancisi, V.; Gobbi, G.; Torricelli, F.; Donati, B.; Ribisi, S.; Gugnoni, M.; Ciarrocchi, A. RAIN Is a Novel Enhancer-Associated lncRNA That Controls RUNX2 Expression and Promotes Breast and Thyroid Cancer. Mol Cancer Res. 2020, 18, 140-152. [CrossRef]

77. Catalanotto, C.; Cogoni, C.; Zardo, G. MicroRNA in Control of Gene Expression: An Overview of Nuclear Functions. Int. J. Mol. Sci. 2016, 17, 1712. [CrossRef] [PubMed]

78. Friedman, R.C.; Farh, K.K.; Burge, C.B.; Bartel, D.P. Most mammalian mRNAs are conserved targets of microRNAs. Genome Res. 2009, 19, 92-105. [CrossRef]

79. Bartel, D.P. MicroRNAs: Target recognition and regulatory functions. Cell 2009, 136, 215-233. [CrossRef]

80. Bartels, C.L.; Tsongalis, G.J. MicroRNAs: Novel biomarkers for human cancer. Clin. Chem. 2009, 55, 623-631. [CrossRef] [PubMed]

81. Ospina, D.; Villegas, V.E.; Rodriguez-Leguizamon, G.; Rondon-Lagos, M. Analyzing biological and molecular characteristics and genomic damage induced by exposure to asbestos. Cancer Manag. Res. 2019, 11, 4997-5012. [CrossRef]

82. Santarelli, L.; Gaetani, S.; Monaco, F.; Bracci, M.; Valentino, M.; Amati, M.; Rubini, C.; Sabbatini, A.; Pasquini, E.; Zanotta, N.; et al. Four-miRNA Signature to Identify Asbestos-Related Lung Malignancies. Cancer Epidemiol. Biomark. Prev. 2019, 28, 119-126. [CrossRef]

83. Reid, G.; Pel, M.E.; Kirschner, M.B.; Cheng, Y.Y.; Mugridge, N.; Weiss, J.; Williams, M.; Wright, C.; Edelman, J.J.; Vallely, M.P.; et al. Restoring expression of miR-16: A novel approach to therapy for malignant pleural mesothelioma. Ann. Oncol. 2013, 24, 3128-3135. [CrossRef] [PubMed]

84. Bandi, N.; Zbinden, S.; Gugger, M.; Arnold, M.; Kocher, V.; Hasan, L.; Kappeler, A.; Brunner, T.; Vassella, E. miR-15a and miR-16 are implicated in cell cycle regulation in a Rb-dependent manner and are frequently deleted or down-regulated in non-small cell lung cancer. Cancer Res. 2009, 69, 5553-5559. [CrossRef] [PubMed]

85. Mozzoni, P.; Ampollini, L.; Goldoni, M.; Alinovi, R.; Tiseo, M.; Gnetti, L.; Carbognani, P.; Rusca, M.; Mutti, A.; Percesepe, A.; et al. MicroRNA Expression in Malignant Pleural Mesothelioma and Asbestosis: A Pilot Study. Dis. Markers 2017, 2017, 9645940. [CrossRef]

86. Santarelli, L.; Strafella, E.; Staffolani, S.; Amati, M.; Emanuelli, M.; Sartini, D.; Pozzi, V.; Carbonari, D.; Bracci, M.; Pignotti, E.; et al. Association of MiR-126 with soluble mesothelin-related peptides, a marker for malignant mesothelioma. PLoS ONE 2011, 6, e18232. [CrossRef] 
87. Tomasetti, M.; Staffolani, S.; Nocchi, L.; Neuzil, J.; Strafella, E.; Manzella, N.; Mariotti, L.; Bracci, M.; Valentino, M.; Amati, M.; et al. Clinical significance of circulating miR-126 quantification in malignant mesothelioma patients. Clin. Biochem. 2012, 45, 575-581. [CrossRef]

88. Ferrari, L.; Carugno, M.; Mensi, C.; Pesatori, A.C. Circulating Epigenetic Biomarkers in Malignant Pleural Mesothelioma: State of the Art and critical Evaluation. Front. Oncol. 2020, 10, 445. [CrossRef]

89. Guarrera, S.; Viberti, C.; Cugliari, G.; Allione, A.; Casalone, E.; Betti, M.; Ferrante, D.; Aspesi, A.; Casadio, C.; Grosso, F.; et al. Peripheral Blood DNA Methylation as Potential Biomarker of Malignant Pleural Mesothelioma in Asbestos-Exposed Subjects. J. Thorac. Oncol. 2019, 14, 527-539. [CrossRef]

90. Fischer, J.R.; Ohnmacht, U.; Rieger, N.; Zemaitis, M.; Stoffregen, C.; Kostrzewa, M.; Buchholz, E.; Manegold, C.; Lahm, H. Promoter methylation of RASSF1A, RARbeta and DAPK predict poor prognosis of patients with malignant mesothelioma. Lung Cancer 2006, 54, 109-116. [CrossRef] [PubMed]

91. Cavallari, I.; Urso, L.; Sharova, E.; Pasello, G.; Ciminale, V. Liquid Biopsy in Malignant Pleural Mesothelioma: State of the Art, Pitfalls, and Perspectives. Front. Oncol. 2019, 9, 740. [CrossRef]

92. Weber, D.G.; Johnen, G.; Bryk, O.; Jockel, K.H.; Bruning, T. Identification of miRNA-103 in the cellular fraction of human peripheral blood as a potential biomarker for malignant mesothelioma-a pilot study. PLoS ONE 2012, 7, e30221. [CrossRef] [PubMed]

93. Santarelli, L.; Staffolani, S.; Strafella, E.; Nocchi, L.; Manzella, N.; Grossi, P.; Bracci, M.; Pignotti, E.; Alleva, R.; Borghi, B.; et al. Combined circulating epigenetic markers to improve mesothelin performance in the diagnosis of malignant mesothelioma. Lung Cancer 2015, 90, 457-464. [CrossRef] [PubMed]

94. Cavalleri, T.; Angelici, L.; Favero, C.; Dioni, L.; Mensi, C.; Bareggi, C.; Palleschi, A.; Rimessi, A.; Consonni, D.; Bordini, L.; et al. Plasmatic extracellular vesicle microRNAs in malignant pleural mesothelioma and asbestos-exposed subjects suggest a 2-miRNA signature as potential biomarker of disease. PLOS ONE 2017, 12, e0176680. [CrossRef]

95. Kirschner, M.B.; Cheng, Y.Y.; Badrian, B.; Kao, S.C.; Creaney, J.; Edelman, J.J.; Armstrong, N.J.; Vallely, M.P.; Musk, A.W.; Robinson, B.W.; et al. Increased circulating miR-625-3p: A potential biomarker for patients with malignant pleural mesothelioma. J. Thorac. Oncol. 2012, 7, 1184-1191. [CrossRef]

96. Matboli, M.; Shafei, A.E.; Azazy, A.E.; Reda, M.; El-Khazragy, N.; Nagy, A.A.; Ali, M.A.; Sobhi, M.; Abdel-Rahman, O. Clinical evaluation of circulating miR-548a-3p and -20a expression in malignant pleural mesothelioma patients. Biomark. Med. 2018, 12, 129-139. [CrossRef] [PubMed]

97. Matboli, M.; Shafei, A.E.; Ali, M.A.; Gaber, A.I.; Galal, A.; Tarek, O.; Marei, M.; Khairy, E.; El-Khazragy, N.; Anber, N.; et al. Clinical significance of serum DRAM1 mRNA, ARSA mRNA, hsa-miR-2053 and lncRNA-RP1-86D1.3 axis expression in malignant pleural mesothelioma. J. Cell. Biochem. 2019, 120, 3203-3211. [CrossRef] [PubMed]

98. Lamberti, M.; Capasso, R.; Lombardi, A.; Di Domenico, M.; Fiorelli, A.; Feola, A.; Perna, A.F.; Santini, M.; Caraglia, M.; Ingrosso, D. Two Different Serum MiRNA Signatures Correlate with the Clinical Outcome and Histological Subtype in Pleural Malignant Mesothelioma Patients. PLoS ONE 2015, 10, e0135331. [CrossRef]

99. Weber, D.G.; Brik, A.; Casjens, S.; Burek, K.; Lehnert, M.; Pesch, B.; Taeger, D.; Bruning, T.; Johnen, G. Are circulating microRNAs suitable for the early detection of malignant mesothelioma? Results from a nested case-control study. BMC Res. Notes 2019, $12,77$. [CrossRef] [PubMed]

100. Hendry, S.; Salgado, R.; Gevaert, T.; Russell, P.A.; John, T.; Thapa, B.; Christie, M.; van de Vijver, K.; Estrada, M.V.; GonzalezEricsson, P.I.; et al. Assessing Tumor-Infiltrating Lymphocytes in Solid Tumors: A Practical Review for Pathologists and Proposal for a Standardized Method from the International Immuno-Oncology Biomarkers Working Group: Part 2: TILs in Melanoma, Gastrointestinal Tract Carcinomas, Non-Small Cell Lung Carcinoma and Mesothelioma, Endometrial and Ovarian Carcinomas, Squamous Cell Carcinoma of the Head and Neck, Genitourinary Carcinomas, and Primary Brain Tumors. Adv. Anat. Pathol. 2017, 24, 311-335. [CrossRef]

101. Klikovits, T.; Stockhammer, P.; Laszlo, V.; Dong, Y.; Hoda, M.A.; Ghanim, B.; Opitz, I.; Frauenfelder, T.; Nguyen-Kim, T.D.L.; Weder, W.; et al. Circulating complement component $4 \mathrm{~d}(\mathrm{C} 4 \mathrm{~d})$ correlates with tumor volume, chemotherapeutic response and survival in patients with malignant pleural mesothelioma. Sci. Rep. 2017, 7, 16456. [CrossRef]

102. Ghanim, B.; Hoda, M.A.; Klikovits, T.; Winter, M.P.; Alimohammadi, A.; Grusch, M.; Dome, B.; Arns, M.; Schenk, P.; Jakopovic, M.; et al. Circulating fibrinogen is a prognostic and predictive biomarker in malignant pleural mesothelioma. Br. J. Cancer 2014, 110, 984-990. [CrossRef] [PubMed]

103. Vogl, M.; Rosenmayr, A.; Bohanes, T.; Scheed, A.; Brndiar, M.; Stubenberger, E.; Ghanim, B. Biomarkers for Malignant Pleural Mesothelioma-A Novel View on Inflammation. Cancers 2021, 13, 658. [CrossRef]

104. Hamaidia, M.; Staumont, B.; Duysinx, B.; Louis, R.; Willems, L. Improvement of malignant pleural mesothelioma immunotherapy by epigenetic modulators. Curr. Top. Med. Chem. 2016, 16, 777-787. [CrossRef] [PubMed]

105. Sigalotti, L.; Coral, S.; Altomonte, M.; Natali, L.; Gaudino, G.; Cacciotti, P.; Libener, R.; Colizzi, F.; Vianale, G.; Martini, F.; et al. Cancer testis antigens expression in mesothelioma: Role of DNA methylation and bioimmunotherapeutic implications. Br. J. Cancer 2002, 86, 979-982. [CrossRef]

106. Baas, P.; Scherpereel, A.; Nowak, A.K.; Fujimoto, N.; Peters, S.; Tsao, A.S.; Mansfield, A.S.; Popat, S.; Jahan, T.; Antonia, S.; et al. First-line nivolumab plus ipilimumab in unresectable malignant pleural mesothelioma (CheckMate 743): A multicentre, randomised, open-label, phase 3 trial. Lancet 2021, 397, 375-386. [CrossRef] 
107. Remon, J.; Reguart, N.; Corral, J.; Lianes, P. Malignant pleural mesothelioma: New hope in the horizon with novel therapeutic strategies. Cancer Treat. Rev. 2015, 41, 27-34. [CrossRef] [PubMed]

108. Vandermeers, F.; Hubert, P.; Delvenne, P.; Mascaux, C.; Grigoriu, B.; Burny, A.; Scherpereel, A.; Willems, L. Valproate, in combination with pemetrexed and cisplatin, provides additional efficacy to the treatment of malignant mesothelioma. Clin. Cancer Res. 2009, 15, 2818-2828. [CrossRef]

109. Paik, P.K.; Krug, L.M. Histone deacetylase inhibitors in malignant pleural mesothelioma: Preclinical rationale and clinical trials. J. Thorac. Oncol. 2010, 5, 275-279. [CrossRef]

110. Scherpereel, A.; Berghmans, T.; Lafitte, J.J.; Colinet, B.; Richez, M.; Bonduelle, Y.; Meert, A.P.; Dhalluin, X.; Leclercq, N.; Paesmans, M.; et al. Valproate-doxorubicin: Promising therapy for progressing mesothelioma. A phase II study. Eur. Res. J. 2011, 37, 129-135. [CrossRef]

111. Hurwitz, J.L.; Stasik, I.; Kerr, E.M.; Holohan, C.; Redmond, K.M.; McLaughlin, K.M.; Busacca, S.; Barbone, D.; Broaddus, V.C.; Gray, S.G.; et al. Vorinostat/SAHA-induced apoptosis in malignant mesothelioma is FLIP/caspase 8-dependent and HR23B-independent. Eur. Res. J. 2012, 48, 1096-1107. [CrossRef] [PubMed]

112. Krug, L.M.; Kindler, H.L.; Calvert, H.; Manegold, C.; Tsao, A.S.; Fennell, D.; Ohman, R.; Plummer, R.; Eberhardt, W.E.; Fukuoka, K.; et al. Vorinostat in patients with advanced malignant pleural mesothelioma who have progressed on previous chemotherapy (VANTAGE-014): A phase 3, double-blind, randomised, placebo-controlled trial. Lancet Oncol. 2015, 16, 447-456. [CrossRef]

113. Amatori, S.; Bagaloni, I.; Viti, D.; Fanelli, M. Premature senescence induced by DNA demethylating agent (Decitabine) as therapeutic option for malignant pleural mesothelioma. Lung Cancer 2011, 71, 113-115. [CrossRef]

114. Leclercq, S.; Gueugnon, F.; Boutin, B.; Guillot, F.; Blanquart, C.; Rogel, A.; Padieu, M.; Pouliquen, D.; Fonteneau, J.F.; Gregoire, M. A 5-aza-2'-deoxycytidine/valproate combination induces cytotoxic T-cell response against mesothelioma. Eur. Res. J. 2011, 38, 1105-1116. [CrossRef]

115. Bensaid, D.; Blondy, T.; Deshayes, S.; Dehame, V.; Bertrand, P.; Gregoire, M.; Errami, M.; Blanquart, C. Assessment of new HDAC inhibitors for immunotherapy of malignant pleural mesothelioma. Clin. Epigenet. 2018, 10, 79. [CrossRef] [PubMed]

116. Donati, B.; Lorenzini, E.; Ciarrocchi, A. BRD4 and Cancer: Going beyond transcriptional regulation. Mol. Cancer 2018, 17, 164. [CrossRef]

117. Riganti, C.; Lingua, M.F.; Salaroglio, I.C.; Falcomata, C.; Righi, L.; Morena, D.; Picca, F.; Oddo, D.; Kopecka, J.; Pradotto, M.; et al. Bromodomain inhibition exerts its therapeutic potential in malignant pleural mesothelioma by promoting immunogenic cell death and changing the tumor immune-environment. Oncoimmunology 2018, 7, e1398874. [CrossRef] [PubMed]

118. Amorim, S.; Stathis, A.; Gleeson, M.; Iyengar, S.; Magarotto, V.; Leleu, X.; Morschhauser, F.; Karlin, L.; Broussais, F.; Rezai, K.; et al. Bromodomain inhibitor OTX015 in patients with lymphoma or multiple myeloma: A dose-escalation, open-label, pharmacokinetic, phase 1 study. Lancet Haematol. 2016, 3, e196-e204. [CrossRef]

119. Manzotti, G.; Ciarrocchi, A.; Sancisi, V. Inhibition of BET Proteins and Histone Deacetylase (HDACs): Crossing Roads in Cancer Therapy. Cancers 2019, 11, 304. [CrossRef] [PubMed]

120. Sancisi, V.; Gandolfi, G.; Ambrosetti, D.C.; Ciarrocchi, A. Histone Deacetylase Inhibitors Repress Tumoral Expression of the Proinvasive Factor RUNX2. Cancer Res. 2015, 75, 1868-1882. [CrossRef]

121. Pili, R.; Quinn, D.I.; Hammers, H.J.; Monk, P.; George, S.; Dorff, T.B.; Olencki, T.; Shen, L.; Orillion, A.; Lamonica, D.; et al. Immunomodulation by Entinostat in Renal Cell Carcinoma Patients Receiving High-Dose Interleukin 2: A Multicenter, SingleArm, Phase I/II Trial (NCI-CTEP\#7870). Clin. Cancer Res. 2017, 23, 7199-7208. [CrossRef] [PubMed] 